Proceedings of the International Conference on Teaching, Education and Learning Conference, Vol. 1, 2021, pp. 63-73 Copyright @ 2021 iConferences

ISSN 2820-2155

DOI: https:/doi.org/10.32789/tel.2021.1005

From The Training Room to the Classroom: Applying Concepts of Corporate Training and Tertiary Education in Secondary Education

\author{
Nathan Polley
}

Christian Heritage College, Australia, nathan.polley@gmail.com 


\title{
FROM THE TRAINING ROOM TO THE CLASSROOM: APPLYING CONCEPTS OF CORPORATE TRAINING AND TERTIARY EDUCATION IN SECONDARY EDUCATION
}

\begin{abstract}
The COVID-19 pandemic has changed the nature of secondary education and encouraged teaching through blended and e-learning. This article explores how the author integrated concepts he previously applied in tertiary education and corporate training, particularly Finks Taxonomy of Significant Learning and P3 Task Taxonomy, through blended and e-Learning to a secondary education context. These ideas developed into a teaching methodology for a business curriculum and were delivered in an international Christian school in Cambodia. The teaching methodology helped streamline curriculum development, adapt to the changing conditions, and improve overall lesson delivery. The study recommends that the teaching methodology be explored further and be developed as a framework to support new and developing teaching staff.
\end{abstract}

Keywords: Finks Taxonomy of Significant Learning, P3 Task Taxonomy, blended learning, secondary education

\section{Introduction}

The swift and unexpected COVID-19 pandemic in the 2019/2020 and 2020/2021 school years left many governments and school administrators on the backfoot and led to many school changes. This transition has been uncomfortable for many educators, with evidence reflecting higher stress in educators and turnover in teaching staff (Diliberti, Schwartz, and Grant, 2021). A further challenge for international schools was various government calls for expatriates to return 'home' and the subsequent imposition of border closures, flight delays, and quarantine restrictions. These factors encouraged administrators and educators to seek blended and e-Learning solutions for the 2020-2021 academic year delivered by new staff outside of secondary education.

I am one such example, having relocated to Cambodia from Australia as the COVID-19 outbreak began. As I found it difficult to secure a tertiary education or corporate training role, I accepted a position in an international school in the Cambodian capital, Phnom Penh. While new to secondary education, I had been a corporate trainer in Australia, Papua New Guinea, and New Zealand and a tertiary educator in Australia and New Zealand and was familiar with blended learning and e-Learning. Could my experience and the concepts I previously applied be successfully migrated to an international school context and secondary classroom?

This article explores how I adopted and adapted concepts I previously applied in corporate training and tertiary education to develop a secondary business curriculum and a teaching methodology. The article then explores the classroom application and results and discusses implications for transitioning educators, secondary education, and international schools. 


\section{Background context}

Cambodia is a nation in South-East Asia that has experienced rapid economic and social development since the late 1990s. Phnom Penh now has numerous public and private schools of varying quality targeting different demographics. The 'School' in this study was a reputable Christian K-12 institute following a United States (US) curriculum (based on Virginia standards) and catering to Christian and non-Christian families. My role was developing and delivering a 'business' curriculum for students from Grade 9 to 12 with elective courses in project management, entrepreneurship, and leadership.

Like many nations, the 2019-2020 and 2020-2021 academic years were not 'normal' with various interruptions to school activities. Government restrictions postponed Khmer New Year from April to August 2020 and prevented school start by four weeks - significantly reducing the number of teaching days in the 2020/2021 academic year. Ongoing restrictions also meant the School had to alternate between teaching online and face-to-face and through different schedules. These changing conditions meant the curriculum and delivery methods had to facilitate face-to-face, blended, and e-Learning often with little notice. The need for flexibility meant lessons were prepared in advance in an e-Learning format and adapted based on the conditions.

\section{Curriculum design and development}

I knew from experience that e-Learning development could be time-intensive, so I sought to adopt concepts from corporate training for 'rapid deployment' of e-Learning using a systematic and sequential approach to course and lesson development. To support this approach, I grouped associated tasks into key phases to form a teaching methodology that I refined across the academic year based on learners' feedback. The seven phases were:

1. Understanding the vision, context, and learner outcomes;

2. Forming a teaching and learning philosophy;

3. Course design;

4. Learning design;

5. Lesson and assessment preparation;

6. Teaching and learning;

7. Analysis and review.

Most phases emphasised curriculum development and occurred at the beginning of the academic year. Teaching and learning, analysis, and review were interrelated and systematically occurred across the academic year. Appendix 1 shows a schematic of this methodology.

\section{Vision, context, and outcomes}

Curriculum development was rooted in the concept of 'constructive alignment.' The curriculum was 'constructive' by enabling knowledge to be constructed through the activities of the learner (Shuell, 1986; Biggs, 2014) and aligned to the school vision and values, Expected School-Wide Learning 
Results (ESLR), standards, learning outcomes, activities and assessments to produce the intended learning experience (Biggs and Collis, 2014). The School vision, values, and ESLR's formed an overarching school-wide framework while standards, learning outcomes, essential questions, and assessments were course-specific. These ESLR's sought holistic education by improving student academic achievement, social awareness and engagement, and spiritual maturity (in their respective faiths).

\section{Developing a teaching and learning philosophy}

Despite my earlier classroom experience, it was apparent that I had to reconsider and contextualise my teaching and learning philosophy. Research by Hattie (2009) found the teacher was the most influential factor in learner achievement (Hattie, 2015; Donohoo, 2016), with teacher qualities and beliefs contributing to around $20 \%$ to $25 \%$ of learning variation in a classroom (Hattie, 2015). Identifying and developing my philosophy about teaching and learning were essential in preparing a successful learning journey.

The School philosophy sought to integrate Christian faith and values within each course. In practice, this extended to teacher conduct, learning materials, lesson planning, and teacher-student relationships as these were perceived to influence classroom teaching. Consistent with the School philosophy and worldview, I drew from Biblical principles of teaching and learning. I found 'knowledge' in Hebrew based on two key terms - da'ath and yada (Orr, 1995). At a simple level, da'ath refers to internal and objective knowledge that comes through mental reasoning. In contrast, yada refers to subjective knowledge developed through intimacy and experience - although the text is often less absolute in these distinctions. The concept that knowledge is also social and rational aligned with my pedagogical philosophy that learning is socially constructed through discourse between learners and between teachers and students. This belief meant I perceived myself as a learning guide rather than an expert (though I was knowledgeable in each topic).

The Greek texts of the New Testament further categorise knowledge into ginosko, epiginosko, and oida (Orr, 1995). The most common - ginosko, refers to incomplete knowledge that is ongoing and relational. For St Paul, this ginosko knowledge should lead to epiginosko - intensive and precise knowledge, accurate and correct, and finally oida - a complete knowledge of Christ that shapes theological thought and personal behaviour. These concepts encouraged me to view learning as a form of spiritual and economic formation that will develop as students transition to university. My role as a classroom educator is to help foster learners' ideas, skills, and values to guide their later business practices.

When planning the course, I recognised the importance of learners anchoring learning to their context - including their family, career, and Cambodia. 'Impact projects' in each course allowed students to authentically develop academically, socially, and spiritually as they applied business knowledge and skills in a project to create 'social impact.' As most projects required teamwork and leadership, servant leadership was taught and applied as it resonated with the School ethos and tradition and focused on moral, spiritual, relational, emotional, conceptual, and personal development. 


\section{Finks Taxonomy of Significant Learning}

My learning philosophy encouraged me to apply Finks Taxonomy of Significant Learning (i.e., Finks Taxonomy) as the basis for curriculum design. Finks Taxonomy has six complementary dimensions or 'petals' designed to create significant learning - learning how to learn, foundational knowledge, application, integration, human dimension, and caring (Fink, 2013; pp. 21-22). Where the earlier Blooms Taxonomy formed a basis for cognitive development as learners progressed from knowledge construction through to the 'higher' order thinking of analysis, synthesis, and evaluation, Finks Taxonomy provided a framework for developing a breadth of learning that aligned with the ESLR's and the School vision and mission.

Finks Taxonomy has been used in various tertiary education studies (Levine et al., 2008; Jenkins, 2016), but few studies have explored its use in secondary education. Of the tertiary education studies, one explored multi-discipline course redesigns and found significant, positive changes across disciplines in the areas of foundational knowledge, application, human dimension, and learning how to learn (Levine et al., 2008). Other studies applied Finks Taxonomy to a tertiary course in cultural leadership and found the taxonomy supported learner achievement, received high course and teacher satisfaction ratings, improved community engagement, and led to higher enrolments (Fallahi et al., 2009; Jenkins, 2016). A final study found dimensions of 'human dimension,' and 'caring' helped create personal development (Taylor-Greathouse, 2013)

\section{P3 Task Taxonomy}

The nature of entrepreneurship, project management, and leadership encouraged a project-based learning approach. I chose the P3 Task Taxonomy based on earlier tertiary experience with the taxonomy (Kathiravelu, Kirk, and Polley, 2020) and because it incorporated project-based learning. The three Ps in the P3 Task Taxonomy of practice, problem-solving, and project-based learning were integrated through simple quizzes and short answers, applying this knowledge in problem-solving and later using these in impact projects. Table 1 summarises the integration.

Table 1: P3 Task Taxonomy

\begin{tabular}{|l|l|l|}
\hline P3 Task & Course & Integration of P3 Task \\
\hline \multirow{4}{*}{ Practice } & $\begin{array}{l}\text { Project } \\
\text { Management }\end{array}$ & $\begin{array}{l}\text { Learners completed short quizzes at the end of several units and short } \\
\text { answer questions after each lesson about project management } \\
\text { methodologies, principles, and practices. }\end{array}$ \\
\cline { 2 - 3 } & Entrepreneurship & $\begin{array}{l}\text { Learners completed short answer questions after each lesson about } \\
\text { aspects of entrepreneurship. }\end{array}$ \\
\cline { 2 - 3 } Problem- & Leadership & $\begin{array}{l}\text { Learners completed short answer questions after each lesson about } \\
\text { leadership concepts. }\end{array}$ \\
\cline { 2 - 3 } solving & $\begin{array}{l}\text { Project } \\
\text { Management }\end{array}$ & $\begin{array}{l}\text { Learners created and defended components of project plans. Problem- } \\
\text { solving occurred in groups and individually and in supervised and } \\
\text { unsupervised settings. }\end{array}$ \\
\cline { 2 - 3 } & Entrepreneurship & $\begin{array}{l}\text { Learners created and defended components of a business plan to peers } \\
\text { and potential investors. }\end{array}$ \\
\hline
\end{tabular}




\begin{tabular}{|l|l|l|}
\hline & Leadership & $\begin{array}{l}\text { Learners presented and defended a personal leadership philosophy } \\
\text { focused on their context that drew on moral, spiritual, relational, } \\
\text { emotional, conceptual, and personal development. }\end{array}$ \\
\hline \multirow{3}{*}{$\begin{array}{l}\text { Project-based } \\
\text { learning }\end{array}$} & $\begin{array}{l}\text { Project } \\
\text { Management }\end{array}$ & $\begin{array}{l}\text { Learners collectively executed an 'impact' project to create a market for } \\
\text { or Non-Government Organisations (NGO's) and student businesses. }\end{array}$ \\
\cline { 2 - 3 } & Entrepreneurship & $\begin{array}{l}\text { Learners launched a small business and ran this for several months. } \\
\text { Learners reflected on their experience and shared findings with peers. }\end{array}$ \\
\cline { 2 - 3 } & Leadership & $\begin{array}{l}\text { Learners executed an 'impact' project to create social capital within the } \\
\text { school community, often through School clubs. }\end{array}$ \\
\hline
\end{tabular}

Research by Barak and Assal (2018) on the P3 Task Taxonomy in a secondary STEM-orientated robotics course found this contributed to high student engagement levels. However, they also found some students did not perform well in project-based learning. The assessment and lesson design sought to use practice questions to scaffold later problem-solving and project-based learning to prepare students for the impact projects.

\section{Course and learning design}

Most of these courses were unique in secondary education which there was limited guidance in the Virginia standards. In-house standards were developed from the ESLR's and aligned to the dimensions of acquisition and processing of knowledge and research (academic achievement), spiritual formation (spiritual maturity), and professional communication and social development (social awareness and engagement). The four assessments - an academic portfolio (i.e., the 'practice' component of the P3 Task Taxonomy), a portfolio of their personal philosophy and impact project planning (i.e., problembased learning), and a portfolio of progress in implementing their impact project (i.e., project-based learning) each aligned to the five domains. Most assessments ran across multiple units, with relevant segments assessed at the end of each unit.

Each unit lasted for a fortnight and comprised five or six lessons. Units were designed around a template 'skin' that included document links to lessons, features, and structured activities. For example, class presentations were often used as a reflection and assessment activity in the final lesson. The short length enabled regular feedback through fortnightly surveys and smaller but more consistent assessments. Together, these factors meant a unit could be developed into a predictable and flexible 'chunk' and released to students as an e-Learning module before the unit commenced and adapted to be blended learning as conditions allowed. 'Essential questions' in these units helped signpost unit topics and themes.

A tool known as the 'Coherence Matrix' helped streamline the course design and storyboarding. The Coherence Matrix helped develop course aims and outcomes and plan assessments, units, and lessons through iterative development as different components were deconstructed and compared. The Coherence Matrix and unit skins (i.e., the e-Learning teaching canvas) were concurrently reviewed and approved, removing the need for individual storyboards and reducing the lesson development time.

\section{Teaching and learning}

Teaching tools, activities, and assessments were designed and selected to capture learner evidence seamlessly. Key tools included a learning management system (LMS) that housed lessons, student 
questions/answers, and assessment submissions, an interactive quiz platform to collect in-class responses, a collaboration board to capture student thoughts, and video conferencing software to support e-Learning. These tools helped combine visual, auditory, and kinesthetic learning in the four broad assessments. The lesson design also sought to improve learner engagement through class discussions, jigsaw exercises, and group work - although, in practice, this was better when there were fewer concurrent student projects in the second semester than in the first.

\section{Analysis and review}

A common feature in my corporate and professional training was feedback forms. In contrast, the School did not have a systematic unit evaluation in their courses. The teaching methodology applied feedback surveys at the end of each unit, providing meaningful feedback from students for formal analysis. Feedback and analysis were further discussed with learners in class - as discussed further below. Moderation was incomplete due to the limited opportunities for in-country internal or external moderation.

\section{Data collection and analysis}

The teaching methodology loosely integrated an action research approach to curriculum development and teaching and learning where data was collected, analysed, and then used as the basis for refinements. Data collection and analysis drew from student results, activities, and feedback collected at each unit's conclusion. The four feedback categories in the unit evaluation were overall satisfaction (with the unit), positive aspects of the unit, aspects of the unit that require immediate improvement, and how the learner could answer the essential question. Results were captured, categorised, and related against the ESLR. This information was then aggregated (to protect privacy) and shared with students for further discussion at the next unit's beginning. Additional suggestions were noted and integrated into subsequent units.

\section{Results}

Student feedback was largely positive and consistent with 'good' courses delivered for the first time. In quantitative terms, most ratings ranged from $80 \%$ to $100 \%$, and course averages ranged between $85 \%$ to $95 \%$, but there were too few participants to conclude teaching methodology's effectiveness using student ratings. After initial 'teething' issues were addressed, feedback generally improved and remained consistent. One issue was the initial perception by learners of the overwhelming workload, which led to some units being adapted or lengthened to accommodate student learning better. Other examples were moving at-home learning assignments from the lesson to Google Classroom to better integrate with student schedules and signpost teacher expectations.

Changes occurred in response to the changing COVID-19 conditions. Lesson length changed three times during the year as classes transitioned between face-to-face and online delivery. At times, lessons were assigned as e-Learning modules to reduce the time allocated in-class to learning facilitation. The flexibility of the teaching methodology supported the short units and flexible assessment design. However, releasing all the assessments at the beginning of the academic year contributed to the student's 
overwhelming sense. This approach differed from other School teachers - even if the assessment level and load were comparable to other courses.

Finks Taxonomy and P3 Task Taxonomy facilitated holistic learning as it encouraged a broad approach to learning and assessment built on foundational knowledge then integrated and applied this in projects. Some learners found the methodology with its taxonomy and pedagogy meant different learning as they conducted primary research, evaluated secondary research, created plans, and undertook projects. For new learners, this was particularly challenging due to COVID-19 restrictions on movement and association.

Although each ESLR was addressed through and in each portfolio and impact project, evidence showed this was not proportionate. A higher proportion of student feedback pointed to academic and social development than spiritual development. This reflects how academic and social development were assessed through two dimensions while spiritual development was assessed in one dimension and with less relative importance; in effect, spiritual development accounted for around $10 \%$ of the overall grade. As the curriculum focus was 'business' and not theology, this allocation was appropriate. Inclusion of spirituality through the Finks Taxonomy 'petals' of the human dimension and caring encouraged a broader and more holistic approach to business education as learners engaged spiritually to address social needs.

Some feedback suggests this approach may not suit all learners or contexts. When School administrators allowed elective choices in semester two, student numbers in Project Management dropped. When interviewed, some students felt the course was not practical in the early units (i.e., emphasis was on project management theory and not doing a project - as the course name suggests). Other students felt the courses were too difficult for 'electives' or were too fast-paced given other courses' expectations and the use of blended or e-Learning. Though helpful, this teaching methodology must adapt to learner context and expectations.

\section{Discussion}

The impact of COVID-19 continues to shape education within and beyond the classroom. A parallel internal and informal School survey on well-being found that students and staff struggled with the transition between online, face-to-face, and blended learning - a trend some learners noted in their feedback. Research from other nations and contexts further confirms this, with evidence showing some learner achievement (Kuhfeld et al., 2020) and mental health (Chaturvedi, Vishwakarma, and Singh, 2021) dropped towards the end of the 2019-2020 and 2020-2021 academic years for students who experienced lockdowns. Due to COVID-19, it is difficult to know how effective this methodology is in 'normal' classroom conditions.

The use of the P3 Task Taxonomy and Finks Taxonomy were consistent with earlier studies. As earlier research found (Kathiravelu, Kirk, and Polley, 2020), transitioning students to the P3 Task Taxonomy can be challenging and take time. Later improvements in feedback could reflect that engaged learners may have stayed while learners disengaged by or through the methodology may have left - but it is impossible to know from this evidence. Application of Finks Taxonomy allowed broader integration of the ESLR's and learning outcomes - even if this was disproportionate, supporting earlier findings in 
tertiary studies (Levine et al., 2008). Christian institutes that apply Finks Taxonomy to support spiritual development must consider how this holistically integrates across and within courses.

Some differences were evident between my experiences in tertiary and secondary education. Developing and assigning assessments at the beginning of the course - a best-practice concept in tertiary education, adversely impacted students and made courses inflexible in the multiple COVID-19 changes. Yet, the predictable structure of e-Learning units helped create consistency and direction. These lessons illustrate how educators must consider the classroom culture and the school and contextualise lessons to their learners.

The teaching methodology supported my transition from tertiary to secondary education, particularly adopting the School's Christian ethos and adapting to the US curriculum. This suggests the methodology may be most appropriate for professional development in new or transitioning teachers in international schools. As international schools experience high turnover (Mancuso, Roberts and White, 2010), struggle to find replacement staff and often recruit an international teaching body (Hayden, 2006), a teaching methodology that guides the development of pedagogical philosophy, creates a shared pedagogical framework and guides curriculum and course development may improve the onboarding process. Furthermore, this teaching methodology may also help create a shared understanding of teaching and learning between teachers and within the School.

\section{Conclusion}

The COVID-19 pandemic changed how teaching and learning in secondary education occur in international schools and Cambodia. This study demonstrates that tertiary educators or trainers can migrate with their experience, tools, and philosophies into secondary education, and their associated teaching methodologies may support secondary education. While the teaching methodology requires further support and research, it offers opportunities to strengthen teacher development and transition.

\section{Acknowledgements}

I want to acknowledge the input of Brad Barrett in the development of this article. Brad worked with me in formulating the teaching methodology and analysing the evidence.

\section{References}

Barak, M. and Assal, M. (2018) 'Robotics and STEM Learning: Students' Achievements in Assignments According to the P3 Task Taxonomy--Practice, Problem Solving, and Projects', International Journal of Technology and Design Education, 28(1), pp. 121-144.

Biggs, J. (2014) ‘Constructive alignment in university teaching', HERDSA Review of Higher Education, 1(July), p. 106.

Biggs, J. B. and Collis, K. F. (2014) Evaluating the Quality of Learning: The SOLO Taxonomy (Structure of the Observed Learning Outcome). Academic Press.

Chaturvedi, K., Vishwakarma, D. K. and Singh, N. (2021) 'COVID-19 and its impact on education, social life and mental health of students: A survey’, Children and Youth Services Review, p. 121. 
Diliberti, M. K., Schwartz, H. L. and Grant, D. (2021) Stress Topped the Reasons Why Public School Teachers Quit, Even Before COVID-19. Research Report RR-A1121-2. RAND Corporation.

Donohoo, J. A. M. (2016) Collective Efficacy: How Educators' Beliefs Impact Student Learning. Thousand Oaks, California: Corwin.

Fallahi, C. R. et al. (2009) ‘Using Fink’s Integrated Course Design: How a Book Changed Our Students’ Learning, Our University, and Ourselves', New Directions for Teaching and Learning, (119), pp. 43-52.

Fink, L. D. (2013) Creating significant learning experiences: an integrated approach to designing college courses, pp. 21-22.

Hattie, J. (2009) Visible learning: a synthesis of over 800 meta-analyses relating to achievement. London; New York: Routledge, pp. 1-17.

Hattie, J. (2015) 'The applicability of Visible Learning to higher education', Scholarship of Teaching and Learning in Psychology, 1(1), pp. 79-91.

Hayden, M. (2006) Introduction to International Education: International Schools and their Communities. SAGE, p. 105.

Jenkins, T. S. (2016) ‘Culture, Leadership, and Activism: Translating Fink’s Taxonomy of Significant Learning into Pedagogical Practice’, Multicultural Learning and Teaching; Berlin, 11(1), pp. 113-130.

Kathiravelu, G., Kirk, D. and Polley, N. (2020) 'Project-based and Collaborative Learning in a software development diploma: Ideas borrowed from mainstream education', in International Conference on MultiDisciplinary Research Studies and Education. Online: Institute For Engineering Research and Publication.

Kuhfeld, M. et al. (2020) 'How is COVID-19 affecting student learning?', Brookings, 3 December. Available at: https://www.brookings.edu/blog/brown-center-chalkboard/2020/12/03/how-is-covid-19-affecting-studentlearning (Accessed: 17 March 2021).

Levine, L. E. et al. (2008) 'Creating Significant Learning Experiences across Disciplines', College Teaching, 56(4), pp. 247-254.

Mancuso, S. V., Roberts, L. and White, G. P. (2010) 'Teacher retention in international schools: The key role of school leadership', Journal of Research in International Education, 9(3), pp. 306-323.

Orr, J. (1995) The International standard Bible encyclopedia. Grand Rapids, Mich.: W.B. Eerdmans.

Shuell, T. J. (1986) ‘Cognitive Conceptions of Learning’, Review of Educational Research, 56(4), pp. 411-436.

Taylor-Greathouse, P. (2013) Adolescent Literacy Practices and Positive Youth Development through Fink's Taxonomy of Significant Learning. Ph.D. University of South Florida. 
Appendix

Appendix 1: Teaching Methodology

Teaching and
learning
philosophy
$\begin{gathered}\text { Wide Learning } \\ \text { Results }\end{gathered}$
$\begin{gathered}\text { School vision, } \\ \text { mission and } \\ \text { values }\end{gathered}$
$\begin{gathered}\text { Learning } \\ \text { Context }\end{gathered}$
philosophy

